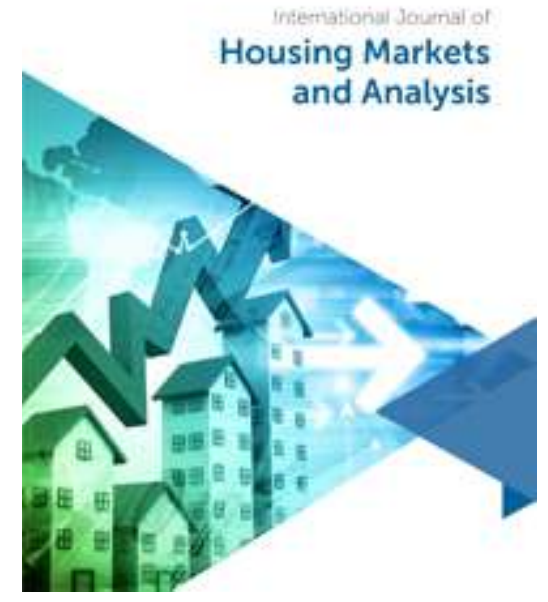

UNITED KINGDOM GENERAL ELECTIONS AND THE IMPACT ON HOUSE PRICES

\begin{tabular}{|r|l|}
\hline Journal: & International Journal of Housing Markets and Analysis \\
\hline Manuscript ID & IJHMA-04-2020-0047.R1 \\
\hline Manuscript Type: & Research Paper \\
\hline Keywords: & $\begin{array}{l}\text { Housing, Housing markets, Housing policy, Housing market analysis, } \\
\text { Residential property, Housing prices }\end{array}$ \\
\hline
\end{tabular}




\title{
UNITED KINGDOM GENERAL ELECTIONS AND THE IMPACT ON HOUSE PRICES
}

\begin{abstract}
Over the last two decades, many developed countries have experienced notable changes in house prices. This explanatory study considers if house price movements in the UK can be linked to the political cycle as governments realize homeowners represent a large portion of the voter base and their voting decisions could be influenced by the magnitude and direction of house price changes. Specifically, the paper investigates whether house prices behave differently before and after elections and under different political regimes. To examine this relationship, the study analyzed quarterly UK national house price data since 1960, along with data on the results of UK parliamentary elections during the same period. Over this period, real annual UK house prices increased by an average of $2.84 \%$. While there is no evidence that house prices in the UK performed significantly differently under different political parties, we observed that house prices performed much better in the last year before an election, compared to the first year after an election. On average house prices increased by $5.3 \%$ per annum in the last year before an election compared to $1.3 \%$ per annum in the first year following an election. The study, thus, highlights significant variations in the performance of UK house prices around election times. It is imperative, therefore, that the political cycle is given adequate consideration when making residential property investment decisions.
\end{abstract}

Keywords: Housing markets, residential house prices, political business cycle, government policies, homeownership characteristics, United Kingdom 


\section{INTRODUCTION}

Housing is a vital and unique asset class with investment, asset and consumption dimensions. The housing sector is also a very integral and sensitive part of the national and global macroeconomies (Baffoe-Bonnie, 1998; Levitin \& Wachter, 2013; Pintér, 2019). It is a key component of social wellbeing in providing shelter and as a source of economic activity with new residential supply and ongoing housing alternations and maintenance requirements. Importantly, for most individuals and families in the UK, housing represents their main investment. Therefore, a vibrant and sound housing market is an important component of the UK's prosperity and, as such, prospective governments controlling the various aspects of housing is a core long-term government mandate. Consequently, the type and timing of policies across various levels of government - local, regional and central - can have far-reaching effects on house prices.

House price movements create a lot of interest and media coverage in the UK, in part, this is due to the residential ownership profile, see Figure 1.

\section{Figure 1:}

\section{UK Home Ownership Profile}

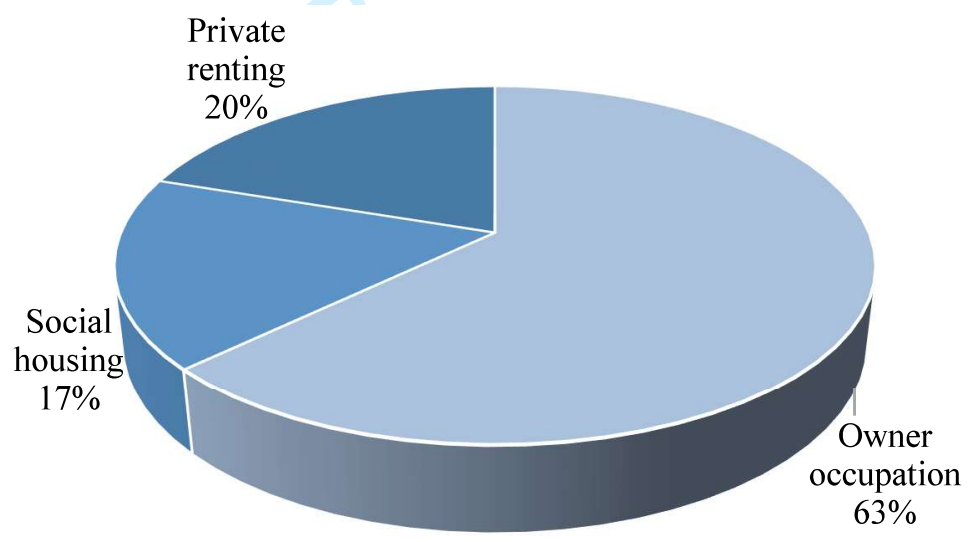

Source: Department for Communities and Local Government 2016

Figure 1 shows the extent of private homeownership across the UK. There are approximately 28 million residential properties of which $63 \%$ are owner-occupied with the owners either owning outright or are paying off a mortgage on the property (ONS, 2016).

Although neo-classical economic theory suggests that house prices are determined by supply and demand forces, the housing market also operates within a dynamic open system, indicating that factors external to the housing system can impact house prices. As housing is important to social wellbeing, governments often feel the need to regulate the housing market and since homeowners represent a large percentage of the voter base, housing-related policies implemented close to an election may influence their voting behaviour.

A growing body of literature finds evidence to the effect that governments sometimes attempt to manage the economy in line with their political motives by the use of both fiscal and monetary policy (see for example Brander and Drazen 2005, Heckelman and Wood 2005, Wood and Stockhammer 2020). As monetary and fiscal policies are of 
fundamental importance to the housing and housing finance market, the impact and consequences of politically-motivated decisions on the housing market can be considerable yet because of the complexities of housing systems, not all eventualities are predictable or taken into account. If a link between house prices and the political cycle could be defined, research on residential house price dynamics and property cycles may be enriched by taking into account political variables.

The purpose of this research, therefore, is to investigate the relationship between UK housing market performance and political climate. This is achieved by examining real price movements over a defined period for the UK residential housing market. For this research, we utilised a long-run series of house price data with coverage from 1960 to 2017. We examined house price movements before and after all elections held within this period and compared the performances thereof to the long-term real average returns.

The intent of this research is not to recommend particular political parties in any way but to highlight a unique approach for examining the impact of the political and voting cycles on residential property performance. Moreover, it is not within the scope of the present research to examine specific political factors which impacted house price movements during the political regimes examined.

The remainder of the paper is structured as follows: following this introduction, we provide an overview of the current literature relating to the housing market and political cycles in Section Two. Section Three details our data sources and research methodology. We present our empirical analysis, findings and implications in Section Five. Conclusions and suggested recommendations and contained in section Six.

\section{LITERATURE REVIEW}

A vast amount of literature exists attempting to model national and regional house price movements. Single country time series, as well as multi-country studies, abound explaining house price movements. Among the leading research looking at the UK Housing Market are the works of Meen (2001), Muellbauer and Murphy (1997), Taltavull de la Paz and White (2012), White (2015), and Whitehead and Williams (2011). The basic neoclassical theory of house price determination is that house prices are determined by supply and demand functions, and a dynamic price adjustment process in which a price mechanism operates to bring supply and demand into balance (Muellbauer, 2012). Many studies have therefore modelled house prices along demand and supply analysis and have linked price movements to a host of demographic, macroeconomic, financial, fiscal and regulatory policy variables.

In the long term, demand for housing is driven by such factors as growth in household disposable income, shifts in demographics, including population size and structure, family size and composition, migration, housing taxation, average levels of interest rates, etc. (Al-Masum and Lee, 2019, Meen, 2012; Tsatsaronis \& Zhu, 2004). Similarly, the supply of residential housing is driven in the long term by availability and cost of land, cost of construction, new housing investments and improvements in the quality of existing housing stock. On the other hand, housing markets are intrinsically local and as such growth in housing stock and house prices can be constrained in the short run by factors such as length of planning and construction phases, the inertia of the existing planning schemes, etc. It is important to note that almost the entire literature on house 
price determination agree as to the imperfection and inefficiency of the housing market and as such systemic mispricing can persist (Muellbauer 2012).

Economic thinking has progressed over time and new ways of conceptualising the theory and practice of managing market economies have evolved. Authors such as Marx (1867), Keynes (1936) and Friedman (1962) made immense contributions with the introduction of new theories that shaped economic policies in many jurisdictions. Keynes (1936), in particular, advanced the use of all available powers at the disposal of governments to influence aggregated demand. Importantly, governments have at their disposal fiscal, regulatory and monetary powers including changes in taxation, public expenditure, planning policies and regulating money supply in the economy.

Neo-classical economic analysis of the housing market links the housing market to the macroeconomy mainly via changes in interest rates and availability of credit to households. However, as monetary and fiscal policies are of fundamental significance to the housing and housing finance market, the impact and consequences of politicallymotivated decisions on the housing market can be considerable (King, 2009).

As Higgins and Reddy (2013) illustrated, the extent to which government policies do impact the housing market can be examined by considering the structure of the property market, using the three-market model of the property market proposed by Ling \& Archer, (2012). This simplified model is shown in Figure 2.

\section{Figure 2 Property Market Structure Model}

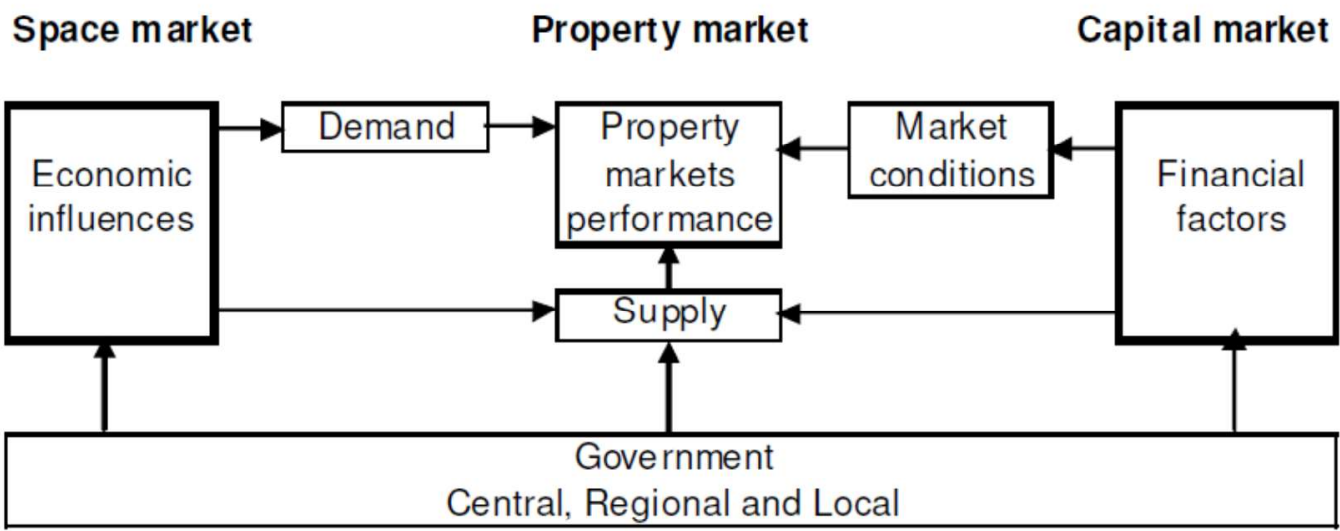

Adapted: Ling \& Archer 2012

Figure 2 indicates that the performance of the real estate market is influenced by a host of forces impacting the space, capital and property market. Within this framework, it can easily be appreciated that several policy-influenced decisions may impact house prices. Many key government policies that may influence UK house prices, for example, population policies such as migration quotas and first-time buyer incentives could be used to boost demand in the space market. Relevant policies in the capital market include base rates and reserve requirements, changes in property taxation such as stamp duty and regulations that impact alternative investment assets. Finally, in the property market, government policies such as rent controls, planning and land-use restrictions and changes in building regulations can constrain housing supply and thereby affect prices.

Government policy, therefore, has an important role to play in house price determination as it has both direct and indirect influences on housing demand and supply variables. If the supply of housing is constrained or demand stimulated by 
government policy, then all things being equal, prices will rise, and vice versa (Adams et al 2005, Wouter van Gent and Hochstenbach 2020). In the United Kingdom, it is often argued that complex and inefficient zoning regulations and a slow authorisation process are among the reasons for the stiffness of housing supply, contributing to both the rise of house prices and their high variability (Girouard et al., 2006).

In providing the tools to manage the economy, government actions may be politically motivated to enhance its chances of (re)election. Nordhuas (1975) introduced this in his Political Business Cycle theory which argues that governments could, by their use of these economic management strategies, manipulate the economy for electoral gains." These have been identified in three key areas:

i) Macroeconomic outcomes: economic growth, lower inflation and lower unemployment etc.

ii) Beneficial rewards: voter tax breaks etc.

iii) Monetary policy: money supply and interest rates (in some countries interest rates are set independently by an appointed organisation, for example, Bank of England).

Source: Ladewig 2008

A common criticism of the literature analysing government strategies and the political business cycle is that of weak conceptual and empirical underpinning (Aidt et al 2019, Drazen 2000 and Keech 1995). Contrary to these debates, studies in the US have found a link between the political business cycle and investment assets. The political business cycle has been linked to the performance of the assets in the equity and bond markets with particular regards to which political parties were in power. Existing studies however provide inconclusive evidence as to which political party provided better returns overall (Ramchander et al 2009, Santa Clara and Valkanov 2003).

In relation to the Housing market, Berry and Dalton (2004) noted the role of past and present government social and housing policies in continuing to fuel belief in the security of homeownership (bricks-and-mortar) as an investment asset class. The impacts of these government policy interventions on the housing market are persistent long-lasting implications on a range of housing market outcomes and with a range of effects, some unanticipated and some conflicting.

Furthermore, Ansell (2019) detailed how housing wealth has an increasing role in shaping individuals contemporary political preferences. Patterns of variation are evident in welfare spending, community identity and voter preferences being increasingly dependent on house values.

In recognising that housing provision cannot be safely left to market forces, successive governments have over the years found it expedient to exercise some form of regulatory control in the housing market particularly housing finance, see Figure 3. 


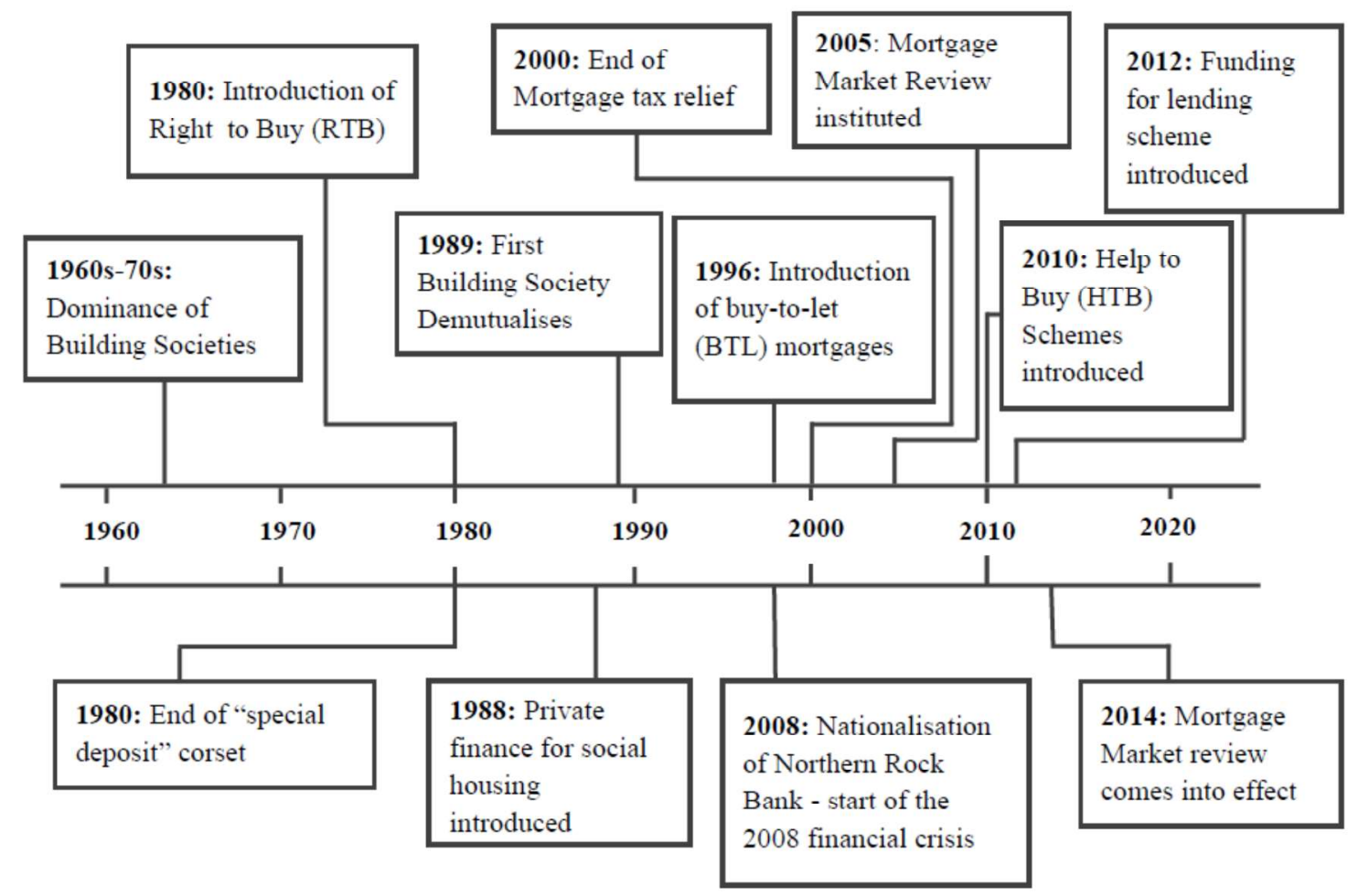

Source: Aha 2021

Figure 3 shows the level of regulatory changes that have shaped the UK housing market. The transformations over time can provide a clear argument about the permanence and inevitability of certain housing market structures can be somewhat misplaced (Williams 2013).

To sum up the foregoing discussion, house price drivers have inextricable interlinkages with governments' macroeconomic, monetary and regulatory policies, which are made in a political environment. As homeowners represent a large part of the voter base, the timing and implementation of these policy interventions could influence housing outcomes and, although difficult to validate, could win the government in power important election votes. Residential property investment decisions therefore ought to take into consideration the political and voting cycles as these could have important implications for housing market performance.

\section{METHODOLOGY}

Across the UK, the performance of the housing market can exhibit significant geographical variations due to local influences. However, according to Nationwide (2017), there is historically a limited divergence of long-term regional performance from that of the overall UK housing market performance. Figure 4 illustrates the longterm UK nominal house price movement since 1960. 


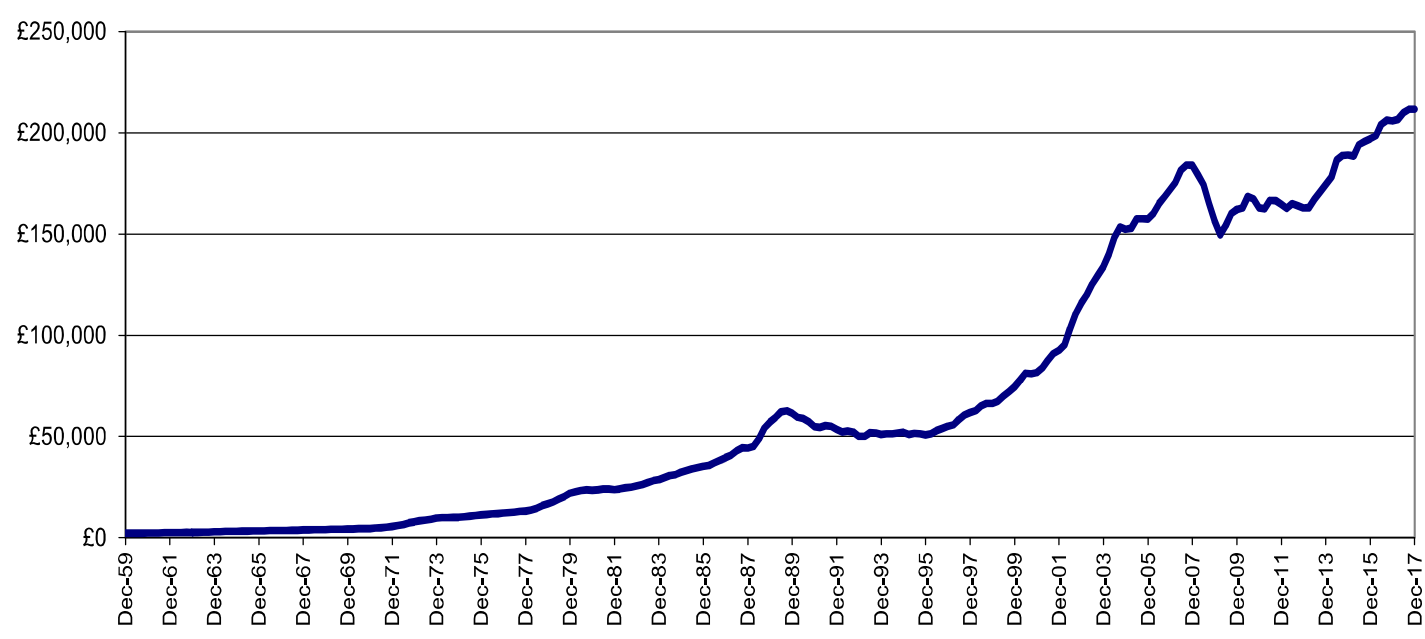

Source: Nationwide 2018

Figure 3 depicts the movement in nominal UK residential house prices. The quarteron-quarter house price growth averages $2.03 \%$ (annualised $8.63 \%$ ). There is significant variation in the level of movement at different episodes of the house market cycle with notable growth occurring from the mid-1990s till the onset of the GFC of 2007/08, leading to a correction which lasted close to two years, but rapid appreciation kicked in again with house prices exceeding pre-crisis levels by the last quarter of 2014 .

In detailing UK house price movement, annualised UK inflation ranged $-1.6 \%$ to $26.6 \%$ over the same period (ONS, 2017). To account for the effect of changes in inflation on a comparison of house prices across different periods, we used real house price data by deflating the nominal prices with the consumer price index (all items) obtained from the ONS databases. With this approach, we were able to consider the movement in house prices independent from external factors.

The parliamentary democratic political system in the UK has been in operation since 1707 with the union of England and Scotland. Key political decisions are made at a national level under the UK parliamentary democracy system with the House of Commons and House of Lords. The central government elections are held every five years under non-mandatory universal adult suffrage for all those of voting age.

Since 1918, the UK political system has been dominated by two parties; Conservatives (Republicans) and Labour (Democrats). Table 1 shows the governments in power and the election dates since 1960 . To ensure consistency with the quarterly house price data, the election dates are shown after the election on a quarterly basis. 
Table 1

UK Government and Election Details

\begin{tabular}{|c|c|c|c|c|c|}
\hline Prime Minister & $\begin{array}{c}\text { Party in } \\
\text { government }\end{array}$ & $\begin{array}{l}\text { Election } \\
\text { Date }\end{array}$ & $\begin{array}{l}\text { Assumed } \\
\text { Office }\end{array}$ & $\begin{array}{c}\text { Retired } \\
\text { from Office }\end{array}$ & $\begin{array}{c}\text { Period of } \\
\text { service } \\
\text { (Quarters) }\end{array}$ \\
\hline Harold Macmillan & Conservative & 08-Oct-59 & Dec-59 & Dec-64 & 20 \\
\hline \multirow[t]{2}{*}{ Harold Wilson } & Labour & 15-Oct-64 & Dec-64 & Jun-70 & 30 \\
\hline & Election & 31-Mar-66 & Mar-66 & & \\
\hline Edward Heath & Conservative & 18-Jun-70 & Jun-70 & Mar-74 & 15 \\
\hline \multicolumn{6}{|l|}{ Eawara Heatn } \\
\hline \multirow[t]{2}{*}{ Harold Wilson } & Labour & $28-\mathrm{Feb}-74^{\#}$ & Mar-74 & Jun-79 & 21 \\
\hline & Election & $10-$ Oct-74 & Dec-74 & & \\
\hline \multirow[t]{2}{*}{ Margaret Thatcher } & Conservative & 03-May-79 & Jun-79 & Jun-97 & 76 \\
\hline & Election & 09-Jun-83 & Jun-83 & & \\
\hline \multirow[t]{3}{*}{ John Major } & Election & 11-Jun-87 & Jun-87 & & \\
\hline & Election & 09-Apr-92 & Jun-92 & & \\
\hline & $P r$ & & & & \\
\hline \multirow[t]{2}{*}{ Tony Blair } & Labour & 01-May-97 & Jun-97 & Jun-10 & 52 \\
\hline & Election & 07-Jun-01 & Jun-01 & & \\
\hline Gordon Brown & Election & 05-May-05 & Jun-05 & & \\
\hline \multirow[t]{2}{*}{ David Cameron } & Conservative & 06-May-10* & Jun-10 & Sept-16 & 27 \\
\hline & Election & 07-May-15 & Jun-15 & & \\
\hline Theresa May & Election & 08-Jun-17 ${ }^{\#}$ & Jun-17 & & \\
\hline $\begin{array}{l}\text { * Coalition gover } \\
{ }^{*} \text { Minority govern }\end{array}$ & & & & & \\
\hline
\end{tabular}

Source: House of Commons Library: UK Election Statistics: 1918-2017

Table 1 details the elected UK Prime Ministers for the past 58 years. There have been 16 UK general elections since 1959 leading to six changes of government. On eight occasions the Conservatives won the most seats while Labour won the most seats on seven occasions. In 2010, the Conservatives won the most seats and entered government in a coalition with the Liberal Democrats. The shortest period of government was the Edward Heath, Conservative-led government (47 months), compared to Margaret Thatcher/ John Major lead governments of over 15 years, having been re-elected three consecutive times.

In analysing the relationship between UK house price movements and the political cycle, we initially examined the data on a decade-by-decade basis using descriptive statistics beginning from 1960. In addition to this, the average house price performance (quarterly growth rate) for the periods during which each elected political party was in office was examined over the periods defined in Table 1.

Besides the performance of the political parties, the impact of the political cycle on house prices was examined by analysing the average quarterly performance of the UK house prices in all the years just before and election and comparing same with the average quarterly performance in the year following an election. This can also be compared to the long-term average house price performance to see if the political cycle does cause deviations from the long-term trend. An important consideration while interpreting the results is that we only take into accounts governments did serve more 
than an 18-month (six quarters) after their election period. This was to minimise noise in the data and highlight only significant differences.

\section{RESULTS}

The first step was to review the descriptive statistics for the UK residential property market over a 10-year interval. This is shown in Table 2.

Table 2 Changes UK Real House Prices Descriptive Statistics: 1960-2017

\begin{tabular}{|lccccccc|}
\hline & 1960 's & 1970 's & 1980 's & 1990 's & 2000 's & $2010-17$ & Total \\
\hline Mean & $3.34 \%$ & $4.35 \%$ & $3.77 \%$ & $-1.36 \%$ & $5.40 \%$ & $1.31 \%$ & $2.84 \%$ \\
Median & $2.52 \%$ & $1.44 \%$ & $5.31 \%$ & $-0.46 \%$ & $8.28 \%$ & $1.79 \%$ & $2.51 \%$ \\
Standard Deviation & $4.43 \%$ & $15.77 \%$ & $10.70 \%$ & $9.88 \%$ & $11.79 \%$ & $6.48 \%$ & $10.70 \%$ \\
Range & $18.26 \%$ & $78.90 \%$ & $59.79 \%$ & $36.04 \%$ & $59.94 \%$ & $32.10 \%$ & $78.90 \%$ \\
Minimum & $-4.23 \%$ & $-27.99 \%$ & $-17.42 \%$ & $-22.33 \%$ & $-26.42 \%$ & $-15.14 \%$ & $-27.99 \%$ \\
Maximum & $14.03 \%$ & $50.91 \%$ & $42.36 \%$ & $13.71 \%$ & $33.52 \%$ & $16.96 \%$ & $50.91 \%$ \\
\hline
\end{tabular}

Table 2 shows that over the last five decades, the average annual percentage change in real UK house prices ranged from $18.26 \%$ in the 1960 s to $78.90 \%$ in the 1970 s. The 2000 's provided strong returns $(5.40 \%)$, being $90 \%$ above the long-term trend $(2.84 \%)$. The volatility in house price movement, especially from the 1970 s to the last decade, was very close to the long-term average of $10.70 \%$.

Besides the measures of central tendency (mean) and variation (standard deviation), the shape of the data can provide valuable information. The skewness shows the symmetry of the data around the mean (low figure preferred) and the kurtosis illustrates the "peakedness" of the data. A high kurtosis reading (above zero) means the data are grouped close to the mean. In each decade, the low skewness and low kurtosis readings demonstrate a flat bell curve as illustrated by high standard deviation readings above $8 \%$ (except for the 1960s and 2010s which had relatively stable house price growth), with a narrow data range of $18.26 \%$ and $32.10 \%$ respectively.

Next, we examined whether the performance of house prices vary under different political regimes. The results are displayed in Table 3 . 


\section{Table 3 Changes in UK House Prices under Different Political Parties}

\begin{tabular}{|lrrr|}
\hline & \multicolumn{1}{c}{ Labour } & \multicolumn{1}{c|}{ Conservative } & \multicolumn{1}{c|}{ Overall } \\
\hline Mean & $2.89 \%$ & $2.80 \%$ & $2.84 \%$ \\
Median & $3.56 \%$ & $2.09 \%$ & $2.51 \%$ \\
Standard Deviation & $10.82 \%$ & $10.65 \%$ & $10.70 \%$ \\
Range & $60.0 \%$ & $70.0 \%$ & $74.0 \%$ \\
Minimum & $-23.1 \%$ & $-19.1 \%$ & $-23.1 \%$ \\
Maximum & $36.9 \%$ & $50.9 \%$ & $50.9 \%$ \\
Count & 86 & 112 & 198 \\
\hline
\end{tabular}

Table 3 indicates a moderately narrow house price range, $2.80 \%$ to $2.89 \%$, between the political parties. This represents a relatively small difference of $\pm 2 \%$ from the overall average of $2.84 \%$. The standard deviation difference would suggest that Labour governments have slightly more volatile returns than the Conservative governments.

A t-statistic was used to examine if the performance of house prices varied significantly under different political regimes. The results are displayed in Table 4.

Table 4

T-Test for Equality of Means

\begin{tabular}{|lc|c|c|c|c|}
\hline & $\begin{array}{c}\text { Mean } \\
\text { Difference }\end{array}$ & $\begin{array}{c}\text { Std. Error } \\
\text { Difference }\end{array}$ & T-test & df & Sig. (2-tailed) \\
\hline $\begin{array}{l}\text { Equal variances } \\
\text { assumed }\end{array}$ & .090 & 1.538 & .059 & 196.000 & .953 \\
\hline $\begin{array}{l}\text { Equal variances not } \\
\text { assumed }\end{array}$ & .090 & 1.541 & .058 & 181.563 & .953 \\
\hline
\end{tabular}

As evidenced from the results shown in Table 4, the t-test illustrated that there is no statistically significant difference ( $t$-values significantly less than 2 ), at $95 \%$ confidence level, in the UK house price performance either under the Labour Party or Conservative Party led House of Commons. The minor difference between the two parties may be attributable to sampling variation, given that the labour party has been in power for 86 quarters compared to 112 quarters of the Conservative government during the period observed in this study.

Table 5 compares the UK house price performance during the first and last years of government by the Labour Party and the Conservative Party. In other words, we examine the behaviour of house prices just before and immediately after elections to see if the elections have any impacts on house prices. 


\section{Table $5 \quad$ Governments First Year and Last Year House Price Performance}

\begin{tabular}{|lcccccc|}
\hline & Conservative Government & Labour Government & \multicolumn{2}{c|}{$\begin{array}{c}\text { Combined } \\
\text { Cons. \& Lab. } \\
\text { Governments }\end{array}$} \\
& First Year & Last Year & First Year & Last Year & First Year & $\begin{array}{c}\text { Last Year } \\
\text { Mean }\end{array}$ \\
Median & $1.06 \%$ & $4.43 \%$ & $1.73 \%$ & $6.70 \%$ & $1.32 \%$ & $5.25 \%$ \\
S.D & $0.98 \%$ & $4.95 \%$ & $4.57 \%$ & $5.22 \%$ & $2.28 \%$ & $4.87 \%$ \\
Range & $4.13 \%$ & $3.61 \%$ & $5.51 \%$ & $4.61 \%$ & $4.66 \%$ & $3.99 \%$ \\
Minimum & $-14.48 \%$ & $35.89 \%$ & $47.13 \%$ & $45.17 \%$ & $50.80 \%$ & $55.03 \%$ \\
Maximum & $-19.03 \%$ & $-13.00 \%$ & $-23.13 \%$ & $-6.26 \%$ & $-23.13 \%$ & $-13.00 \%$ \\
\hline
\end{tabular}

Table 5 reveals marginal differences in UK house price performance during the first years for both Labour and Conservative governments. The average annualised growth in UK house price during the first term of Labour governments was $1.73 \%$, slightly above the $1.06 \%$ recorded by the Conservative governments. A t-test shows that this difference is not statistically significant at a $95 \%$ confidence level. In their last years in power, labour governments recorded an average annualised growth rate of $6.70 \%$ compared to $4.33 \%$ under the Conservative government. This difference, once again, is not statistically significant at a $95 \%$ confidence level. The difference in performance may be related to differences in expenditure policies as Anderson et al (2008) argued that left-of-centre governments are more concerned with controlling unemployment than right-of-centre governments.

Nonetheless, Table 5 illustrates a more remarkable observation; It is perceived that average UK house price performance is much better in the year just before an election relative to the first-year post- election. This was observed to be true irrespective of the party in office. Average annualised house price growth was by $5.25 \%$ in the last years post-election compared to $1.32 \%$ in the first years following an election. This means average house price performance in the years before an election is about $85 \%$ above the long-term average $(2.84 \%)$ and about four times the performance in the first year after an election. On the other hand, the average house price performance one year after an election is about $53 \%$ below the long-term average.

The findings give a strong indication of the possibility that political parties could be seeing house price movements as an important consideration before an election and that elections are usually held during periods of booms in the housing market (and perhaps the economy as a whole). This could be so since Prime Ministers are at liberty, to call for elections at any time and would mostly do so only if they deem there to be a high chance of victory for their party. A strong housing market could be connected with a flourishing economy and serve as an indicator that the party in power may win the election. This is an area that could benefit from an in-depth examination in future research.

While it may be the case that house prices fare well in periods of general economic growth, it is also plausible that given the significant proportion of homeowners in the UK voter base, political parties could use strong house price growth as a tool to secure more votes during elections. In such cases, pre-emptive governments policies to support or stabilise house prices in the short term could reverberate at a later stage with significant consequences on house prices. The long term effect on economic growth 
could be acutely suppressed by affordability issues across the residential property markets.

\section{CONCLUSION}

This research is a preliminary systematic examination of the influence of elections and the political cycle on residential property prices in the UK. We have examined how house prices react to central government elections through the lens of long-term real house price performance in the UK, under different political parties and before and after elections. Over the last five decades, real UK house prices increased at an annualised growth rate of $2.84 \%$. We find only a narrow difference in UK house price performance between Labour and Conservative governments terms in office. However, the most striking finding of this preliminary analysis is that there is significant variation in house price movements one year before, compared to one year after the House of Commons elections. UK house price performance is appreciably better in the year before the elections compared to the year immediately after the election. To quantify, this represents a ratio of about 1:4 and this finding holds irrespective of the political party in power.

In recognising the active role of policymakers in the housing market and the possibility of manipulating house prices for political gains, it must be recognised that such shortterm measures may seem appealing to a large number of voters but could mask fundamental failings in the housing market in the long-term. Leaving these issues unresolved could be more complicated than often perceived.

This study identifies important areas of further research. The political cycle should be recognised as a significant part of the housing market research agenda so that actors in the residential property market could include the election timings as part of the decision-making process. Further research in this area will shed more light on the connections between house prices and political cycles. This can include the performance of the housing market under regime change compared to elections that keep the same party in power. Political studies research may also benefit from enriched models predicting electoral victories if housing market performance variables are considered. 


\section{REFERENCES}

Adams J, 2005, The Structure and Growth of Residential Neighbourhoods in American Cities, Progress in Human Geography, Vol.29, p321-325.

Aha B, 2021, The Dynamic Relationship Between UK Housing Finance, House Prices and their Interplay with Macroeconomic Indicators, Unpublished $\mathrm{PhD}$ Thesis, Birmingham City University, Birmingham.

Aidt T, Asatryan Z, Badalyan L and Heinemann F, 2019, Vote Buying or (Political) Business (Cycles) as Usual? Review of Economics and Statistics, Vol.102, p409- 425.

Al-Masum, M and Lee C, 2019, Modelling Housing Prices and Market Fundamentals: Evidence from the Sydney Housing Market, International Journal of Housing Markets and Analysis, Vol.12, No.4, p746-762.

Anderson P, 2008, The Secret Life of Real Estate and Banking, Shepheard-Walwyn, London.

Ansell B, 2019, The Politics of Housing, Annual Review of Political Science, Vol 22, p165-85

Archer W and Ling D, 2008, Real Estate Principles: A Value Approach, (2nd ed.). McGraw Hill, New York.

Baffoe-Bonnie J, 1998, The Dynamic Impact of Macroeconomic Aggregates on Housing Prices and Stock of Houses: A National and Regional Analysis, Journal of Real Estate Finance and Economics, Vol17, p179-197.

Berry M and Dalton T, 2004, Housing Prices and Policy Dilemmas: A Peculiarly Australian Problem? Urban Policy and Research, Vol 22, No1, p69-91.

Brender, A and Drazen A, 2005, Political Budget Cycles in New Versus Established Democracies. Journal of Monetary Economics, Vol 52, No1, p1271-1295.

Department of Communities and Local Government, 2016, UK Housing Statistics Department of Communities and Local Government, London.

Drazen A, 2000, Political Economy, Princeton University Press, New Jersey.

Friedman M, 1962, Capital and Freedom, University of Chicago Press, Chicago.

Gent W and Hochstenbach C, 2020, The Neoliberal Politics and Socio-spatial Implications of Dutch Post-crisis Social Housing Policies, International Journal of Housing Policy, Vol 20, p156-172.

Girouard N, Kennedy M, Van Den Noord P and André C, 2006, Recent House Price Developments: The Role of Fundamentals, OECD Economics Department Working Papers, No. 475, OECD Publishing. http://dx.doi.org/10.1787/864035447847

Heckelman J and Wood J, 2005, Political Monetary Cycles Under Alternative Institutions: The Independent Treasury and the Federal Reserve. Economics and Politics Vol.17, p331-350.

Higgins D and Reddy W, 2013, Australian House Prices and Political Risk, Australian Property Journal, Vol 4, p125-143.

Keech W, 1995, Economic Politics: The Costs of Democracy, Cambridge University Press, New York. 
King, P, 2009, Understanding Housing Finance: Meeting Needs and Making Choices (2nd ed.). Routledge, Oxon.

Keynes J, 1936, The General Theory of Employment, Interest and Money, Palgrave Macmillan, London.

Kim K, Suh S and Feridum M, 2006, Real Estate Business Cycles and Real Estate Policies: The Case of Korea, Regional and Sectoral Economic Studies, Vol.6, No.1, p57-74.

Ladewig J, 2009, Housing Starts and the Political Business Cycle, American Politics Research, Vol 36, No5, p776-796.

Levitin A and Wachter S, 2013, Why Housing? Housing Policy Debate, University of Pennsylvania Law School, 25 August.

Ling D and Archer W, 2012, Real Estate Principles: A Value Approach. New York, McGraw-Hill Higher Education.

Marx K, 1867, Capital, Volume I. Translated. Fowkes B (1990), Penguin, London.

Meen G. 2001, Modelling Spatial Housing Markets : Theory, Analysis, and Policy, Kluwer Academic Publishers, London.

Muellbauer J, 2012, Housing and the Macroeconomy, International Encyclopaedia of Housing and Home, Vol 3, p 301-314.

Muellbauer J and Murphy A, 1997, Booms and Busts in the UK Housing Market, The Economic Journal, p1701-1727.

Nationwide 2018, UK House Price Index, Nationwide Building Society, Swindon.

Nordhaus W, 1975, The Political Business Cycle, Review of Economic Studies, Vol 42, No2, p169-190.

ONS, 2016, UK Perspectives 2016: Housing and Home Ownership in the UK. Office for National Statistics, Retrieved December 19, 2017, from https://visual.ons.gov.uk/uk-perspectives -2016-housing-and-homeownership-UK/

Pagan A, 1997, Towards an Understanding of Some Business Cycle Characteristics, The Australian Economic Review, Vol.30, No.1, p1-15.

Pintér G, 2019, House Prices and Job Losses, The Economic Journal, Vol.129, Iss.618, p991-1013.

Power J, Jing S and Whaley R, 2007, The Persistent Presidential Dummy: Differences Turn Out to be Insignificant, Journal of Portfolio Management, Vol.33, No.2, p133143.

Ramchander S, Simpson M and Webb J, 2009, Political Cycles, Partisan Orientation, Gridlock, and REIT Returns, Journal of Real Estate Portfolio Management. Vol.15, No. 2, p115 -127.

Ryan-Collins J, Lloyd T, MacFarlane L. 2017, Rethinking the Economics of Land and Housing, Oxford, Taylor and Francis.

Santa Clara P and Valkanov R, 2003, The Presidential Puzzle: Political Cycles and the Stock Market, Journal of Finance, Vol. 58, No. 5, p1841-1872. 
Taltavull de la Paz P and White M, 2012, Fundamental Drivers of House Price Change: The Role of Money, Mortgages, and Migration in Spain and the United Kingdom. Journal of Property Research, Vol. 29, No.4, p341-367.

Tsatsaronis K and Zhu H, 2004, What Drives Housing Price Dynamics : Cross-Country Evidence. BIS Quarterly Review, (March), p65-78.

White M, 2015, Cyclical and Structural Change in the UK Housing Market, Journal of European Real Estate Research, Vol.8, No.1, p85-103.

Whitehead C and Williams P, 2011, Causes and Consequences? Exploring the Shape and Direction of the Housing System in the UK Post the Financial Crisis. Housing Studies, Vol. 26, No.7, p1157-1169.

Wood J and Stockhammer E, 2020, House Prices, Private Debt and the Macroeconomics of Comparative Political Economy, Working Paper 2005, Post Keynesian Society, London.

Van Gent W and Hochstenbach C, 2020, The Neoliberal Politics and Socio-spatial Implications of Dutch Post-Crisis Social Housing Policies, International Journal of Housing Policy, Vol. 20, p156-172. 